HOW Journal

Volume 27, Number 1, pages 69-82

https://doi.org/10.19183/how.27.1.518

HOW

\title{
Enhancing Reading Comprehension through an Intensive Reading Approach
}

\author{
Mejora de la comprensión lectora mediante un método de lectura \\ intensiva
}

Insuasty Cárdenas, Andrés ${ }^{1}$

\begin{abstract}
This article presents a project that explored the effectiveness of intensive reading to enhance reading comprehension with a group of university students in Pasto, Colombia. At the initial stage, a diagnostic test, field notes, and three questionnaires allowed the identification of the students' needs. During the intervention stage, a set of workshops and reading tests were implemented to reveal the impact of the reading comprehension strategies. In the evaluation stage, four instruments (reading tests, teacher's journal, students' questionnaires and pre- and post-tests) were used to collect the students' opinions and state the results. At the end, findings show that the reading comprehension strategies improved students' comprehension because it helped them tackle the problems they had before the intervention stage.

Keywords: intensive reading, reading comprehension, reading process, reading strategies, reading techniques.

\section{Resumen}

Este artículo trata de un proyecto que explora la efectividad de la lectura intensiva para mejorar la comprensión lectora de un grupo de estudiantes universitarios en Pasto (Colombia). En el estado inicial, un examen diagnóstico, diario de campo y tres encuestas permitieron identificar las necesidades

Andrés Insuasty Cárdenas holds a BA in English and French from Universidad de Nariño, Colombia, and an

MA in English Didactics from Universidad de Caldas, Colombia. He is a parttime English language teacher at different universities in Pasto. He is interested in teaching reading and writing to university students.

aginsuasty@iucesmag.edu.co

http://orcid.org/0000-0003-4491-5627

Received: April 19th, 2019. Accepted: September 9th, 2019

This article is licensed under a Creative Commons Attribution-Non-Commercial-No-Derivatives 4.0 International License. License Deed can be consulted at https://creativecommons.org/licenses/by-ncnd $/ 4.0 /$
\end{abstract}


de los estudiantes. Durante la fase de intervención, se aplicaron talleres y exámenes que mostraron el impacto de las estrategias de comprensión de lectura. En la fase de evaluación, se analizaron cuatro instrumentos (exámenes de lectura, diario del profesor, cuestionarios a estudiantes y un pre y post test) para revisar los resultados y opiniones de los estudiantes. Al finalizar este proyecto, los resultados muestran que las estrategias mejoraron la comprensión lectora porque les permitió sortear los problemas encontrados antes de la fase de intervención.

Palabras clave: lectura intensiva, comprensión lectora, proceso de lectura, estrategias de lectura, técnicas de lectura.

\section{Introduction}

Learning a foreign language has become a common trend nowadays. In a globalized world, people need to learn a language for many reasons. Traveling to other countries, getting good job opportunities and having a good professional status are among the most common reasons to learn a language. Nonetheless, learning a foreign language at university level is deemed as a requirement to graduate and to take the Saber PRO test ${ }^{2}$. This is why reading is one of the most important skills in any language class because it is not only a source of information and a pleasurable activity but also a means of consolidating and extending personal knowledge of the language. According to Johnson (2008), reading is a constant process that needs to be improved through practice. By continuously practicing, readers are expected to comprehend the content of a text and the textual meaning by using strategies to identify main ideas and specific information, comprehend grammar structures, and learn new vocabulary. Furthermore, students need to understand what a passage is about and the extent of the information that is given by the teacher.

In general, the importance of reading helps students to be reflective and move from a classical teacher-centered view to a more analytical and comprehensive view. Both teachers and students have to work together to make the reading process something meaningful to their lives. This study then explores the impact of intensive reading with undergraduate students who have not had the opportunity to use reading strategies in the English courses that they take in their majors. In these English courses, teachers focus on grammar most of the time and the main skills (reading, writing, listening and speaking) are scarcely used. Thus, implementing intensive reading appears as a means to improve learning among students. Through reading, students are expected to enhance both productive (speaking and writing) and receptive skills (reading and listening) and to develop literacy which enables them to be more critical thinkers at the moment of expressing their opinions.

Saber PRO is a standardized test taken by undergraduate students as a requirement to graduate and to measure the quality of tertiary education programs. 


\section{Literature Review}

Teaching reading comprehension by intensive reading. Taking into account that reading is not an isolated process because it is linked to the other main skills, Alyousef (2005) defines reading as something interactive. This interaction happens when a reader is in contact with any type of passage and starts a process of analyzing and classifying important information which can be shared and discussed with their peers. Besides, Alyousef (2005) states that reading is something that can help a reader to develop automaticity because the reader can look for relevant information and express their opinions and ideas after reading a text. This is why language teaching approaches have been developed to foster reading comprehension via intensive reading.

According to Mart (2015), intensive reading allows a reader to carry out a detailed analysis inside the class, led by the teacher, in which vocabulary and grammar points are studied in a short passage. Additionally, Brown (2000) calls intensive reading "narrow reading" because it gets students to analyze several texts about the same or different topic. The purpose of intensive reading is to focus on content and grammatical structures. Teachers can also take part in the process by means of reading aloud, asking questions, and having students predict information of texts. In this way, students get opportunities to understand the meaning of a text. Brown (2000) says that the key to intensive reading is to give students more opportunities to be in contact with a text; in this way, the more familiar the reader is with the text, the more comprehension is promoted.

Harmer (2004) asserts that reading is a kind of "springboard" that allows a person to develop the other language skills. He emphasizes that reading is placed in the core of learning; the results might be beneficial for students. Moreover, Evans, Hartshorn, and Anderson (2010) believe that reading can be beneficial if placed as the main base of learning the other language skills. These authors also state that through reading, vocabulary and grammar are developed; consequently, the main skills are possible to be learned.

Anderson's (2008) concept of reading is important to foster reading among students because they can develop literacy if they are exposed to a variety of readings. Nonetheless, other factors (as time, availability of materials, and effective instruction) are necessary to ensure that reading comprehension takes place. Furthermore, Kuhn and Stahl (2003) establish a relationship between intensive reading activities and overall language proficiency. When readers start to read following an intensive reading approach, they can improve both grammar and vocabulary and consequently improve the other main language skills (writing, listening, and speaking).

According to Paran (2003), teachers can make use of intensive reading to maximize students' learning process going through the three phases of the reading process: pre- 
, while-, and post-reading. These phases search for better language preparation, analysis, and activation strategies. In addition, Paran (2003) explains that intensive reading itself is effective for developing reading skills because students in an EFL context can comprehend a text step by step and not as whole. In conclusion, intensive reading is deemed as an effective tool for improving reading comprehension.

Reading process. In the booklet The Professional Development Service for Teachers ${ }^{3}$ (2014), the reading process is defined as something complex and multi-dimensional. Thus, teachers who are assertive when fostering reading comprehension in their classes must know about its complexity. Teachers can make use of a range of teaching approaches that enable students to be confident and independent readers. Aspects to consider in the teaching of reading towards recognizing this complexity are the variety and richness of vocabulary, providing a framework for teaching comprehension strategies, ensuring that students feel motivated, and finding reading as something pleasurable. Each aspect is essential because it provides guidance for understanding how the reading process should be taught.

Carter and Long (1991) explain that these three phases of reading are useful since students have opportunities to follow a reading passage in a more organized and detailed way. Also, each phase has a series of strategies that teachers could use in order to help students understand what they are reading. In the before-reading stage, Paran (2003) argues that teachers need to motivate students through activities that may attract their interest (e.g. book talks, dramatic readings, or pictures related to the text). The goal is to make the text relevant to students in some way. Another strategy suggested by Paran (2003) is by activating students' background knowledge and discussing what students will read, what they already know about the topic, and about the text organization. In this manner, students might establish a purpose for reading, identify and discuss difficult words, phrases, and concepts in the text, preview the text (by surveying the title, illustrations, and unusual text structures), and make predictions about its content.

In the while-reading stage, the teacher takes a role as a guide. They should encourage students to use comprehension strategies as they read, and to monitor their understanding. In this stage, teachers ask students questions to keep track of the reading and to focus their attention on main ideas and important parts of the text. Also, teachers ask their students to pay attention to parts in a text that require making inferences, and students summarize key sections or events. Finally, teachers need to encourage students to confirm the predictions made before. Pang et al. (2003) proposes other strategies that can be used in this stage. These include making connections between and among important ideas in the text, integrating new ideas with existing background knowledge, sequencing events and ideas in the text, checking

This booklet contains detailed information about the reading process and covers many topics regarding reading instruction (reading fluency, comprehension strategies, vocabulary, and assessment). 
understanding by paraphrasing or restating events found in the reading, and identifying characters, settings, or events in a text.

In the post-reading stage, Toprak (2009) expresses that all the ideas are concluded in this stage. This is the summary of the reading material. Here, teachers can make a discussion from the reading, and summarize important ideas as well as supportive details. Also, students recall and tell important parts of the text in their own words. Also, students could respond to the reading in a variety of ways (e.g. by writing, role-playing, music, posters, videos, debate, or pantomime). Other activities that teachers could apply in this stage are evaluating and discussing the ideas found in the text, plus applying and contextualizing ideas in real life situations.

Instructional reading strategies. In order to reinforce the use of intensive reading, instructional strategies which allow students to understand a reading in steps are necessary. These strategies not only provide students with a framework to work when they start comprehending a text but also help consolidate information relevant for the text. Stoller et al. (2013) highlight the importance of using strategies that allow students to understand a text in a more analytical way. They propose strategies that include activating prior knowledge, interacting with the text, and paying attention to details such as vocabulary. In addition, Lewis and Hill (1992) express that it is necessary to activate students' reading comprehension by means of activities implemented before going directly to the reading text. They suggest that teachers should pose questions related to the text or let students brainstorm ideas about the text. Stricklin (2011) also proposes four steps to follow when reading a text: predicting, clarifying, questioning, and summarizing.

Therefore, the use of instructional reading strategies is important because these enable students to know what to do in every reading stage. The reading strategies implemented in this study are shown below.

Know, Want, and Learn (KWL) chart. This reading strategy proposed by Ogle (1986) helps students organize their ideas in a more detailed way. This strategy elicits students' prior knowledge of the topic of the text, establishes a purpose for reading, and helps students to monitor their comprehension.

Survey, Question, Read, Recite, and Review (SQ3R). This is a five-phase reading strategy in which students can make a structural process when reading a passage. Biringkanae (2018) explains that SQ3R helps students understand a text while reading it. Firstly, students need to Survey, it means that they skim through the pages assigned in order to get a "general idea" about what the chapter, section, or article is about. In this part, students organize their ideas about the text and predict what it will be about. In Question, students ask questions based on the titles, headings, or subheadings surveyed in the first stage. In the third stage, students have the chance to Read. This stage is the most important because the goal is to answer the 
stated questions after reading. In this stage, additionally, students may highlight unknown vocabulary, jot down relevant information in the passage, and ask further questions to discuss after reading. Once students have read the passage, in the Recite stage, students put away their notes and organize their ideas either on paper or out loud. In this stage, students organize the information gathered in the previous section on their own. Finally, students Review the text by using all the information they collected; they also create something different with the information gathered (e.g. create flashcards, make a map, table, and diagram, make a timeline or tell someone else their ideas).

Directed Reading Thinking Activity (DRTA). According to Behroozizad (2018), it is a reading technique in which students ask questions about a text, make predictions, then read to confirm or modify their predictions. The DRTA technique guides students to be active and thoughtful readers by enhancing their comprehension. This strategy enables students to monitor their understanding of the text as they are reading; in this way, they can reinforce their reading and critical thinking skills. In this strategy, teachers present the reading material and ask questions about the text. The goal is to activate students' prior knowledge and give opinions about the text. Then, they give their prediction about what would happen in the text in the next section. Also, teachers can ask questions in order to have students think and predict. Finally, after reading each pre-selected section, they confirm and modify their predictions based on the supporting statements in the text.

Vocabulary Self-selection Strategy (VSS). Antonacci and O'Callaghan (2011) assert that this strategy allows students to collect and learn new words that they may encounter in texts and in the oral language that surrounds them every day. The goal is to develop word consciousness. As described by Ruddell and Shearer (2002), the method can be implemented in this way: First, teachers select a reading passage and read it aloud; then, a determined word is selected to be shown to students by highlighting its importance in the text. After that, teachers share out a reading passage and ask students to read it. At the end, students choose a certain number of unknown words, write them on the vocabulary sheet and justify why they are important for them.

Story Maps. Adler (2004) states that the use of story maps allows students to organize and learn the elements of a story since those are graphic organizers. In the story maps, students identify story characters, plot, setting, problem, and solution. Therefore, students should read carefully to learn the details. Of course, there are many different types of story map graphic organizers. This strategy is useful when students want to organize a story in parts to have a better understanding and identify the main parts of a reading passage.

Compare and Contrast Diagrams. Praveen and Rajan (2013) explain that this strategy has to do with establishing similarities and differences between two people, places, animals, etc. by fostering deep thinking among students when comparing two concepts. Students 
could use many templates; the most common is a Venn diagram. Teachers can use other diagrams to apply in class. According to Dreher and Gray (2009), the use of diagrams in reading is beneficial because students need to scan a text to summarize and write down important ideas by completing a diagram. The role of teachers is to model by reading a similar text aloud and showing students how the diagrams work. In that way, students can understand the purpose of the task they are going to work.

\section{Method}

Action research was carried out in order to get both teachers and students involved in that practice, with the aim to change and improve aspects found in a determined context (Kemmis, McTaggart, \& Nixon, 1992). Action research is therefore a process of enquiry carried out as a practitioner as to the effectiveness of one's own teaching and students' learning. Research is more systematic and collaborative in collecting evidence on which to base theories and reflections. This involves problem-posing, not just problem-solving. It does not start from a view of 'problems' as something impossible to solve, but motivated by a search to improve and understand the world by changing it and learning how to improve it from the effects of the changes made.

Context of the study. This study was developed with a group of undergraduate students taking the English level III course as a requirement for graduation at a private university in Pasto, Colombia. There are four faculties at this institution; each of them offers two programs. Students are required to take elective courses such as ethics, institutional philosophy, and English. Regarding the English area, the courses are offered by the University's Language Center that offers four levels. Each level varies according to the academic program. There are over 15 teachers, and the majority holds a master's degree and works as adjunct teachers.

Participants. The participants of this project were sixteen students of third semester from the Computer Engineering Program, fourteen males and two females. Their ages ranged from 19 to 24 years old. They took the English courses as a requirement to graduate in their major. Their level of English language proficiency was between A1 and A2. They consider English as something important both in their major and in their professional life. In fact, the implementation of this project with this group was to see the impact of intensive reading for future accounts in the English language teaching at this institution.

Data collection and analysis. Mathison (1988) highlights the importance of using different data collection procedures in a study to obtain reliable data from a variety of sources simultaneously. During the diagnostic stage, different instruments were implemented in order to know about the strengths and difficulties of the English language teaching process in the context of study. First, the questionnaires given to the students, university 
language center coordinator, and English language teachers' staff gave evidence of not only relevant information about the students' beliefs and the teachers' views regarding English instruction but also a set of the students' problems with the four language skills. Second, a diagnostic test was applied to see the strengths and weaknesses in the four language skills. Third, a teacher's journal revealed information regarding instruction inside the English language classes. In the action stage, six workshops were implemented using the different reading instructional strategies mentioned above in the literature review. These implemented strategies contributed to check how well the students learned and applied the strategies. During the evaluation stage, four different instruments were applied: three reading tests, three questionnaires, a pre- and post-test and a teacher's journal to check both performance and opinions coming from the students.

Diagnostic stage. After analyzing the questionnaires and tests, several aspects needed to be improved regarding language teaching. During the analysis, the instruments were revised to_find categories and codes to identify the problem. The following figure provides information about the categories encountered:

\begin{tabular}{|c|c|}
\hline $\begin{array}{l}\text { Positive } \\
\text { attitude } \\
\text { toward } \\
\text { English }\end{array}$ & $\begin{array}{l}\text { - Students consider the practice of English as something useful in their profesional } \\
\text { lives (Ss questionaire) } \\
\text { - It was evident that students felt motivated to learn English, they liked the activities } \\
\text { and showed interest and participated in class (journal) }\end{array}$ \\
\hline $\begin{array}{l}\text { Need for } \\
\text { reading } \\
\text { practice }\end{array}$ & $\begin{array}{l}\text { - Most of the teachers expressed that reading practice might be possible if there was } \\
\text { more time for instruction. (teachers questionaire) } \\
\text {-....after reading the article, the students had problems understanding the general } \\
\text { idea of the paragraph..." (journal) }\end{array}$ \\
\hline $\begin{array}{c}\text { Lack of } \\
\text { vocabulary }\end{array}$ & $\begin{array}{l}\text { - Students expressed the have problems comprehending texts due to the lack of } \\
\text { vocabulary (Ss questionaire) } \\
\text { - The low results in both reading and writing tests inticate that studens need much } \\
\text { more practice in reading and vocabulary (Diagnostic Test) }\end{array}$ \\
\hline
\end{tabular}

Figure 1. Issues identified during diagnostic stage.

The previous figure displays the main issues attended during the intervention stage. Despite the fact that the students had a positive view of English, some adjustments were necessary to improve their learning process through implementing intensive reading.

Action stage. Taking into account the issues found in the diagnostic stage, six workshops, including instructional reading strategies based on the intensive reading approach, were 
proposed to teach students how to read and comprehend texts in a more analytic way. The time devoted for each workshop was 3 hours, making a total of 30 hours of intervention approximately. The reading materials used in this project included stories, a comic strip, articles, and a fairy tale to expose the students to different types of readings. According to Khoshbakht and Gorjian (2017), language teachers can implement different reading materials other than books into their lessons because they can catch students' attention, increase their comprehension skills, and make them good readers.

In addition, the workshops that followed the reading process stages were divided into pre-, while-, and post-reading tasks. Each task allowed the students to understand every part of the reading passages. The development of the workshops was guided by the teacher who explained the strategies and provided examples to the students before doing each workshop. Finally, after the students did two workshops, they took a reading test including one of the instructional reading strategies seen in class. The results obtained on the tests were analyzed to revise students' use of reading. The following table shows a brief summary of the action stage:

Table 1. Action stage outline.

\begin{tabular}{|c|c|c|c|}
\hline Workshop & Strategy & Type of Reading & Evaluation \\
\hline $\begin{array}{l}\text { 1. Is reality stranger than } \\
\text { fiction? }\end{array}$ & $\begin{array}{l}\text { Know, Want and } \\
\text { Learn (KWL) Chart }\end{array}$ & Short Story & \multirow{2}{*}{ Reading Test 1} \\
\hline 2. Reading is fun & $\begin{array}{l}\text { Survey, Question, Read, } \\
\text { Revise, Review (SQ3R) }\end{array}$ & Comic & \\
\hline 3. Computer crimes & $\begin{array}{l}\text { Directed Reading } \\
\text { Thinking Activity (DRTA) }\end{array}$ & Newspaper Article & \multirow{2}{*}{ Reading Test 2} \\
\hline $\begin{array}{l}\text { 4. Getting into the habit } \\
\text { of reading }\end{array}$ & $\begin{array}{l}\text { Vocabulary Self-Selection } \\
\text { Strategy (VSS) }\end{array}$ & Magazine Article & \\
\hline $\begin{array}{l}5 . \quad \text {...and they lived happi- } \\
\text { ly ever after }\end{array}$ & Story Mapping & Fairy Tale & \multirow{2}{*}{ Reading Test 3} \\
\hline 6. Brilliant minds & $\begin{array}{l}\text { Compare and } \\
\text { Contrast charts }\end{array}$ & $\begin{array}{l}\text { Course book } \\
\text { Reading }\end{array}$ & \\
\hline
\end{tabular}

The graph below shows the reading process and the strategies used in each of the reading stages. Each workshop contained the mentioned strategies, assuring that the students learned to understand the readings step by step.

Evaluation stage. In this stage, three reading tests, three questionnaires, a pre- and post-test, and a teacher's journal were applied to check both performance and opinions coming from the students. After having collected and analyzed data from these instruments, the following students' performances and opinions were obtained: 


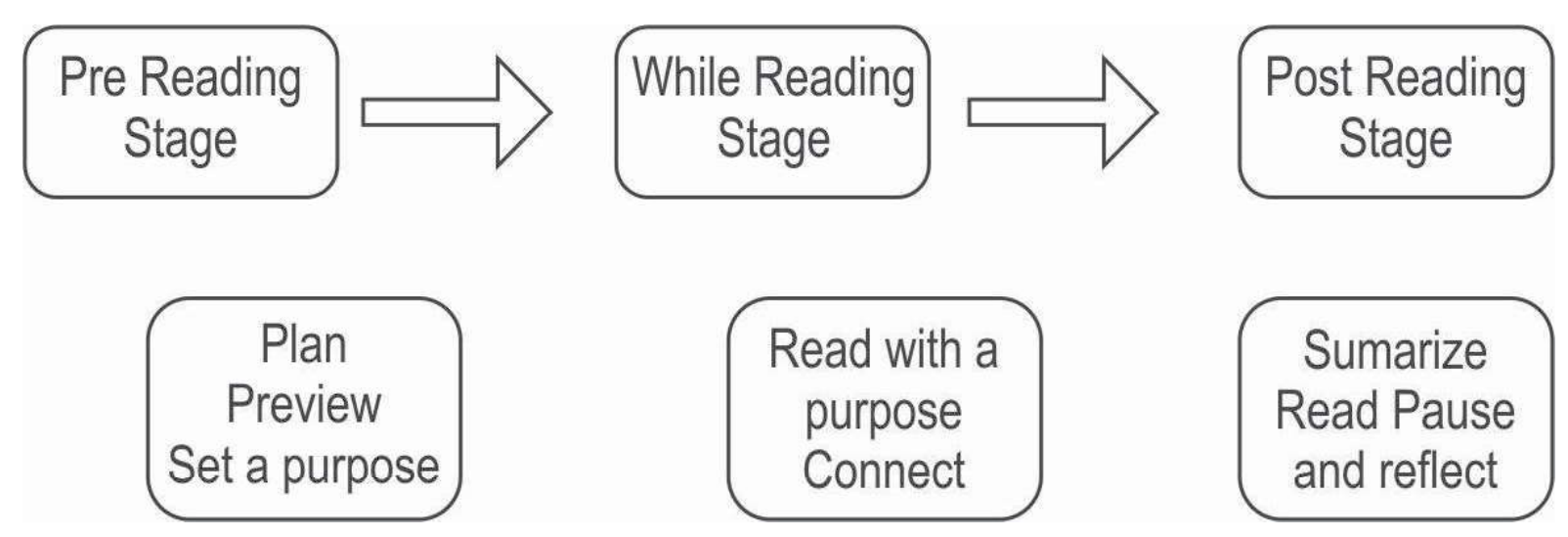

Figure 2. The reading process.

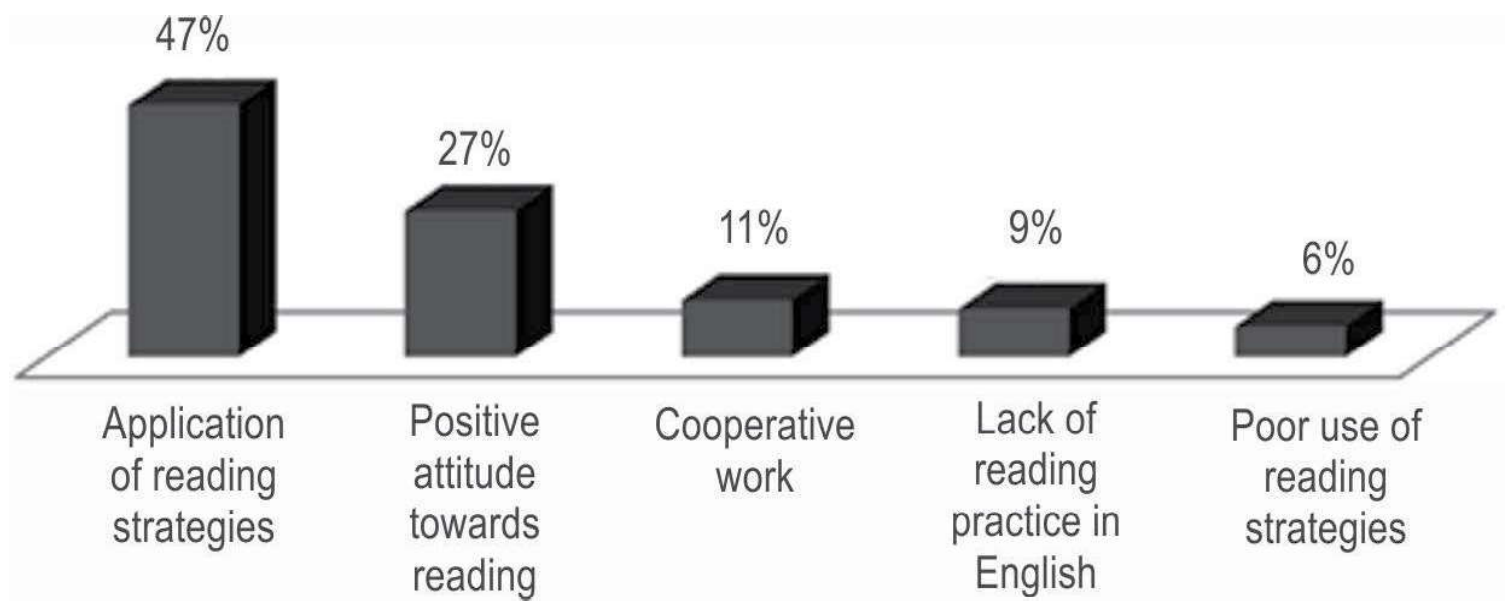

Figure 3. Students' performances and opinions in the Evaluation Stage.

\section{Findings}

After the implementation and the analysis of data from the instruments, the participants believed that the intensive reading approach improved their reading ability and changed their attitude positively. Reading turned into an enjoyable activity for them as they believed that the implemented strategies were useful. Also, the students were able to make predictions before reading, they wrote questions to know the author's purpose, and summarized the ideas after reading. Thus, these results revealed that intensive reading, when it is conducted with the use of comprehension strategies, gave the students a sense of achievement as positive attitude towards reading was enhanced. Some samples are included and identified as follows: SQ1 (Students' questionnaire 1), SQ2 (Students' questionnaire 2), SQ3 (Students' questionnaire 3), TJ (Teacher's Journal entries) and the results obtained on the RT (reading tests, a pretest, three reading tests using the strategies taught and a posttest). 
Positive attitude towards reading. Learning to read by applying the implemented strategies helped the students understand a variety of texts during the course. According to Nation (2001) intensive reading is a gradual process that needs to be done for longterm purposes in which learning and applying the strategies are learnt through a continuous process. The fact that intensive reading is teacher-centered can help students analyze and comprehend a text in depth. Moreover, the workshops helped the students to notice the grammar and vocabulary as they had opportunities to reading different kinds of texts. Consequently, the intensive reading approach was effective to apply it with these students, because they understood what they read. Some of the students' opinions were:

- “me parece que las lecturas están adecuadas al nivel' SQ2

[I think the texts are suitable for our level]

- "las lecturas me parecen interesantes ya que se aprende un poco más" SQ3

- $\quad$ [The texts are interesting because I learn more]

- "Las lecturas han sido interesantes y mejoran nuestro conocimiento" SQ1 [The texts have been interesting and improve our knowledge]

Application of reading strategies. The instructional strategies used in the workshops allowed the students to activate their prior knowledge, to brainstorm ideas, and to become active participants during the workshop. The activities presented in the post-reading stage let the students propose something new that changed the traditional conception of just reading a text without using comprehension strategies. Authentic tasks such as presentations, posters, or graphic organizers allowed the students to summarize what they read. Some of the ideas and opinions taken from the instruments were:

- "The workshop allowed students to summarize and make a whole analysis of the reading passage and increase their vocabulary..." TJ entry 5

- "los talleres de lectura me han ayudado a entender más vocabulario y aplicar estrategias" SQ3

- [The reading workshops helped me understand more vocabulary and apply the strategies]

- "The reading tests helped students to use the strategies in a more structured way following the parts of the text..." RT post-test

Cooperative work. It can be said that intensive reading approach and comprehension strategies had a positive effect on the students' performance regarding making predictions, summarizing, checking for vocabulary, and contextualizing unknown words. Thus, it can be inferred that intensive reading comprehension positively impacted the students' reading comprehension because they improved since they started the reading workshops. A positive change was achieved because the texts were structured following the reading process model to help the students integrate previously existing background knowledge with newly incoming 
data. Another aspect was that the students did collaborative homework in which they had the chance to share important ideas and discuss the texts, despite the fact that they had to work on their own. Some of the ideas and opinions taken about this issue were:

- "me gustó el taller por que el tema me sirvió para aplicar las estrategias, me ba ayudado a entenderlas" SQ2

- [I liked the workshop because it helped me apply and understand the strategies]

- "Students had no problem consolidating and summarizing the story and they felt motivated to doing the workshop" TJ entry 2

- "Students had the chance to apply different strategies during the reading tests and it was beneficial for them" RT

Poor use of reading strategies and lack of reading practice in English. Although the previous findings showed positive results, the students needed more instruction and time when processing the reading material. There were cases in which the students needed more time to analyze a workshop, presumably because of lack of vocabulary and overall language skills. This aspect implies that the students needed more time or a deeper analysis of the strategies to process newly incoming data. For future research, this consideration becomes relevant. Teachers should give students more input, make activities in which they activate their previous knowledge, and bridge the gaps between their reading comprehension and their previous experiences.

\section{Conclusions and Pedagogical Implications}

This action research project offers an alternative for English language teachers to move from a grammar-focused view to a more demanding approach in which students can be more analytical and participative in class. In the meantime, this research has opened a path for reflection, to improve pedagogical practice and further exploration.

Impact of intensive reading among students. The results of this study indicate that the application of intensive reading with university students taking English language classes can be an alternative to involve and motivate students in reading. It also gives teachers in the field the opportunity to increase students' interest about general topics by reading different kinds of texts related to their real lives. At the same time, English language students may reinforce important information about their experiences and account for different sections of a text. Consequently, if students have the chance of reading authentic material, they activate their previous knowledge and increase the amount of vocabulary they need to comprehend unknown vocabulary they may encounter in other contexts. In addition, the use of different reading strategies can help them determine the meaning of the words by using context clues to have a clear understanding of a text, which means that students' interest and motivation for reading in English will be significant. 
Importance of intensive reading among teachers. English language teachers should implement different reading strategies with students to facilitate the reading and understanding process. This becomes significant because teachers may not usually use reading texts in the class. They should realize that reading can be useful inside the class because the strategies of interpreting, connecting, and predicting can help identify both specific and general elements in a text. If teachers implement reading strategies and explain the benefits of reading more and more, students will start using them and be able to comprehend and analyze a text better.

Implementation of reading materials in the class. In addition, it is necessary to foster the use of readings inside the English language classrooms to make students more autonomous and independent readers. Therefore, teachers in the field should go beyond the traditional role of knowledge provider with a grammar-based approach to a more analytical view of language teaching. Students need to learn how to use learning strategies so that they can understand a variety of contexts and be more critical thinkers. As Nyikos and Oxford (1993) state, if students are more aware of the use of a strategy, it is likely they will be able to use it in any real context. In that way, they can overcome their general learning style limitations and use a lot of strategies to process and use new language information.

\section{References}

Adler, C. R. (Ed.) (2004). Put reading first: The research building blocks for teaching children to read (3 ${ }^{\text {rd }}$ Ed.). U.S.: National Institute for Literacy.

Alyousef, H. S. (2005). Teaching reading comprehension to ESL/EFL learners. Language Learning Journal, 5(1), 143-154.

Anderson, N. (2008). Active skills for reading book 4. (2 ${ }^{\text {nd }}$ Ed.) Massachusetts: Heinle Cengage Center.

Antonacci, A. P., \& O’Callaghan, C. M. (2011). Developing content area literacy: 40 strategies for middle and secondary classrooms. London: SAGE Publications, Inc.

Behroozizad, S., \& Habibollahiaghdam, M., (2018). Directed reading-thinking activity and reading comprehension. The Journal of English Language Pedagogy and Practice, 11(22), 111-126.

Biringkanae, A. (2018). The use of SQ3R technique in improving students` reading comprehension. ELS-Journal on Interdisciplinary Studies in Humanities, 1(2), 218-225.

Brown, H. D. (2000). Principles of language learning and teaching ( $4^{\text {th }}$ Ed.) New York: Pearson Education.

Carter, R., \& Long, M. N. (1991). Teaching literature. New York: Longman Inc.

Dreher, M., \& Gray, J. (2009). Compare, contrast, comprehend: using compare-contrast text structures with ELLs in K-3 classrooms. The Reading Teacher, 63(2), 132-141.

Evans, N., Hartshorn, K., \& Anderson, N. (2010). A research based approach to materials development for reading. In N. Harwood (Ed), Materials in ELT: Theory in practice. Cambridge: Cambridge University Press. 
Harmer, J. (2004). How to teach writing. Harlow: UK. Pearson Longman.

Johnson, A. P. (2008). Teaching reading and writing: A guidebook for tutoring and remediating students. Maryland, US: R\&L Education.

Kemmis, S., McTaggart, R., Nixon, R. (1992). The action research planner (3 ${ }^{\text {rd }}$ Ed.). Australia: Springer.

Khoshbakht, F., \& Gorjian, B. (2017). Using authentic materials in teaching reading comprehension to EFL learners. Journal of Applied Linguistics and Language Learning, 3(2), 48-54.

Kuhn, M., \& Stahl, S. (2003). Fluency: A review of developmental and remedial practices. Journal of Educational Psychology, 95(1), 3-21.

Lewis, M., \& Hill, J. (1992). Practical techniques for language teaching. London: Language Teaching Publications.

Mart, C. (2015). Combining extensive and intensive reading to reinforce language learning. Journal of Educational and Instructional Studies in the World, 5(4), 85-90.

Mathison, S. (1988). Why triangulate? Educational Researcher, 17(2), 13-17.

Nation, I. S. P. (2001). Learning vocabulary in another language. Cambridge: Cambridge University Press.

Nyikos, M., \& Oxford, R. (1993). A factor analytic study of language learning strategy use: Interpretations from information-processing theory and social psychology. The Modern Language Journal, 77(1), 11-22.

Ogle, D. (1986). KWL: A teaching model that develops active reading of expository text. The Reading Teacher, 40, 564-570.

Pang, S., et al. (2003). Teaching Reading. Geneva: International Bureau Educational.

Paran, A. (2003). Intensive reading English. Teaching Professional, 28, 40-48.

Praveen, S., \& Rajan, P. (2013). Using graphic organizers to improve reading comprehension skills for the middle school ESL students. English Language Teaching, 6, 155-170.

Professional Development Service for Teachers PSDT (2014). The Reading Process: A Guide to the Teaching and Learning of Reading. Dublin, 2014. Available at: https://pdst.ie/sites/default/ files $/ 15 . \% 20$ The $\% 20$ Reading $\% 20$ Process.pdf

Ruddell, M. R., \& Shearer, B. A. (2002). "Extraordinary," "tremendous," "exhilarating," "magnificent": Middle school at-risk students become avid word learners with the vocabulary selfcollection strategy (VSS). Journal of Adolescent \& Adult Literacy, 45(5), 352-363.

Stoller, F., Anderson, N., Grabe, W., \& Komiyama, R. (2013). Instructional enhancements to improve students' reading abilities. English Teaching Forum, 1, 2-33.

Stricklin, K. (2011). Hands-on reciprocal teaching: A comprehension technique. The Reading Teacher, 64(8), 620-625.

Toprak, E.L, \& Almacioğlu, G. (2009). Three Reading Phases and Their Applications in the Teaching of English as a Foreign Language in Reading Classes with Young Learners. Journal of Language and Linguistic Studies, 5 (1), 21-36. 